\title{
Practice of Action Oriented Teaching for Financial Statements Analysis Course
}

\author{
Hongxia Li \\ Department of Economics and Management \\ Shanghai Customs College \\ Shanghai, China \\ lihongxia@shcc.edu.cn
}

\author{
Sihong Li \\ Department of Economics and Management \\ Harbin University of Science and \\ Technology \\ Harbin, China \\ lisihong@hrbust.edu.cn
}

\author{
Xiaoning $\mathrm{Hu}$ \\ Department of Economics and Management \\ Shanghai Customs College \\ Shanghai, China \\ 18373298263@163.com
}

\begin{abstract}
To cultivate and train students' ability to use statement analysis knowledge to serve their jobs, in the practice of course students complete each task through a four-in-one circulating learning approach featured by "learning knowledgesharing experience-investigating and solving problems creatively-taking practical action". Teachers can increase students' interests in the course and enhances the learning results through the reform of teaching.
\end{abstract}

Keywords-action-oriented teaching; financial statements analysis; teaching reform

\section{The ApPliCATION MEANing OF ACtiOn-Oriented TEACHING CONCEPTS}

"Action-oriented" comes from the German "binary education" model. To meet the workplace requirements to the applied talents, domestic colleges and universities reform the German model. Shanghai Customs College cultivates applied talents for Customs to attain the occupation-required knowledge and ability through action-oriented teaching which makes students complete systematic learning based on customs business in the actual or simulated teaching situation purposefully and systematically. In the practice of actionoriented teaching, teachers use diverse methods in different specific course of teaching. The goal of the cultivation of professional talents is not only "knowledge" but also "goal of professional ability". The teaching design of courses in the field of study make students attains professional competence, method ability and social skills in the study. For teachers, the standard of a bravo lesson is having three of the ability above simultaneously. So there is more space to discuss and study the action-oriented teaching. ${ }^{[1]}$

This article selects the January 1, 2005 to April 10,2017 as the research time period, with the theme of "action-oriented teaching" precise matching as the retrieval condition, and obtain 5854 documentary achievements in CNKI, including 5557 academic journals, 122 master's theses, 2 doctoral dissertations, 231 conference papers and 102 newspaper articles. In the first three months of 2017, 74 articles are needed, and the related research has been increasing year by year. Financial statements analysis combines the essence of accounting, financial managements, business management, finance and behavioral science. The course has a strong practical operation that determines that it is very consistent with the concept of action-oriented teaching and learning. But the action-oriented teaching is not a specific teaching method; it is a complete active learning atmosphere process of teaching. And its essence is a philosophy of instructional design. Different simulation roles of the financial statements in the course can explore the operation situation behind the data offered by the enterprise, have a judgement of effectiveness of the strategic positioning, strategic implementation and the quality of business management and predict the future prospects of the enterprise. The financial statements analysis course usually uses the case teaching method to help students understand the complicated concepts and principles, evaluate the project quality through the project tasks, and mobilize the enthusiasm and initiative of students learning by playing the role of them. In different colleges and universities, different courses in our country, action-oriented teaching application research also have reference value and practical significance.

\section{THE EXPLORATION OF ACTION-ORIENTED TEACHING \\ METHODS IN THE FINANCIAL STATEMENTS ANALYSIS OF COURSE TEACHING}

Action-oriented teaching is a complete and active teaching process and the most important feature of it is learning in action. The essence of action-oriented teaching mode is to guide students to explore practical problems with teaching methods mainly including task-based teaching, role-playing, case teaching, guided teaching based on project, situational teaching method, experimental method, four steps teaching methods and so on. Designing the teaching process is to achieve the report analysis, teaching, and learning integration, 
and integrate the professional competence, method ability and social skills, individual ability in the process of student ability training. ${ }^{[2]}$

\section{A. Action-oriented teaching methods used in the design of the curriculum}

1) Task teaching method

The core idea of this pedagogy is based on tasks. From the point of view of report analysts, to cultivate students' occupational ability, we should do the following: how to link the acquired knowledge with the task, and if we have mastered this professional knowledge, can we finish the task better?

\section{2) Project teaching}

The core idea of the project teaching method is to enable students through a complete project to achieve the link between knowledge and skills, the development of a complete professional ability. Compared with the task teaching method, the core idea of the task teaching method is to integrate the knowledge and task, but to make the students have a complete grasp of the whole work process, and can take the skills and knowledge gained through task teaching Integration into a whole, but also need a relatively large, complete task to start teaching, this is the project teaching.

\section{3) Guided education based on the project method}

In the project of teaching method, in order to meet the students' independent study, the guidance material in teacher development process is mainly for students to decide their own reference. These introductory text materials are referred to as guided texts. This method is commonly used in project teaching. The key factor in determining the company's strategy is the report analysis of relevant industry background information, corporate governance.

\section{4) Based on the project teaching role-playing method}

Through different role-playing in the project team, students can experience the connotation activities of their own characters and experience the psychology of each other characters, so as to fully demonstrate the "as" and "bit" of various roles in the real society, so as to achieve the goal of cultivating students' abilities.

\section{5) The situation teaching method}

The situation teaching method refers to the teachers to create a specific problem situation to stimulate students' enthusiasm for thinking, in order to train students to explore the ways and means of solving the problem independently. Teachers create the situation, and then students find their own ways to solve the problem, to do group discussion, to display, and to do class discussion.

\section{B. The Application of Action Oriented Teaching Method in "Financial Statement Analysis" Course}

Financial statements analysis of the course is characterized by actual combat. In the course students play roles as securities analyst. The listed company report quality analysis tasks are assigned to each team. Competition, mutual evaluation and expert evaluation can improve students’ awareness of competition.
If teachers' roles are understood as the creators of educational activities, teachers will emphasize the subjective initiative of the "common subject" between teachers and students in practical teaching through task-driven and enhanced consciousness of cooperation. Action-oriented emphasizes on "studying in doing" and requires teachers to constantly build up experience and reflect on teaching behavior, to make themselves transfer from an imparter of knowledge to a promoter and a builder to guide students to explore knowledge and analyze the problem-solving methods. Action learning emphasizes that students should organize learning teams and take the four-in-one learning cycle of "Learning Knowledge - Sharing Experiences Creatively Researching and Solving Problems - Starting Real Actions" to complete the entire practice teaching process. Learning in groups can not only conducive to improving the personality and personality development of students, but also develop students' teamwork spirit, sense of cooperation, collective ideas and communication skills. Therefore, the learning process of the action team is not only a cognitive process, but also an emotional interaction and interaction process.

Through the role of simulation based on the project to complete the training of vocational skills in the course content and in the teaching process, the financial analyst job tasks are decomposed into teaching projects and the theory knowledge teaching of financial statement analysis are penetrated with project quality analysis, capital structure projects, profits and other project analysis. And with project quality analysis determines the teaching content. Through action-oriented training, students can enhance their ability of autonomous learning in an all-round way so that in the practice students can systematically gather the ability of creative thinking, gathering professional technical information, tracking professional technical progress and adapting to the needs of vocational skills required by social development and other aspects. ${ }^{[3]}$ Teaching Project Content Design, see table I:

\section{TABLE I. Teaching Project Content Design}

\begin{tabular}{|c|c|}
\hline Work content & $\begin{array}{c}\text { Teaching Project Design } \\
\end{array}$ \\
\hline $\begin{array}{l}\text { Enterprise financial and operational status } \\
\text { analysis }\end{array}$ & $\begin{array}{l}\text { No.1:“Cash is more important than profit” } \\
\text { 1: Assets quality analysis, evaluation of } \\
\text { corporate profitability and operational } \\
\text { capacity; } \\
\text { 2: Capital structure analysis, evaluation of } \\
\text { corporate solvency. }\end{array}$ \\
\hline $\begin{array}{c}\text { Financial Statement Analysis and Securities } \\
\text { Investment }\end{array}$ & $\begin{array}{l}\text { No. 2: "Stock Investment Analysis” } \\
\text { 1: Analysis of the relevant data inside and } \\
\text { outside the report; } \\
\text { 2: Complete the securities analysis report; } \\
\text { 3: Verify stock price=intrinsic } \\
\text { value+ investor sentiment+ manipulation }\end{array}$ \\
\hline $\begin{array}{l}\text { Financial Forecast and Enterprise Value } \\
\text { Assessment }\end{array}$ & $\begin{array}{l}\text { No. 3: "Estimation of the expected future value } \\
\text { of the business" } \\
\text { 1: Design effective financial forecasting } \\
\text { management operating system; master the } \\
\text { predictive analysis of the basic procedures and } \\
\text { methods; } \\
\text { 2: Choose listed company and forecast its } \\
\text { profits, assets, liabilities, } \\
\text { owner's equity and cash flow respectively; } \\
\text { 3: Assess the value of the enterprise; analyze } \\
\text { and confirm the creation of enterprise value. }\end{array}$ \\
\hline
\end{tabular}




\section{ACTION ORIENTED TEACHING EXPERIENCE IN THE} APPLiCATION OF FinANCiAL STATEMENTS ANALYSiS

Experience is gained in implementing the concept of action-oriented instruction in the 3-year "Financial Statement Analysis" course. Through the use of case teaching method to help students understand the complex concepts, the project teaching role-playing method is introduced into the curriculum, which greatly enhances students 'interest in learning and cultivates students' innovative thinking, professional ability and social ability. What gained from the teaching is that the financial statements analysis course is very suitable for the use of action-oriented teaching which plays the following roles in the course of teaching reform:

\section{A. Conducive to cultivating students' innovative thinking ability}

In the completion of the project tasks, students as the main body, the role of teachers is to ask questions and give the basic method. Analysis and evaluation of company quality in the report analysis of listed companies should be done independently by the students and able to exercise their ability of independent thinking and problem solving.

In action-oriented teaching methods, knowledge acquisition is mostly from brainstorming. At this point, the teaching content is no longer static and the answer is no longer unique, which gives students a free imagination, help students to break through the theoretical knowledge of the rules and regulations, so that students more innovative. ${ }^{[4][5]}$

\section{B. Help to improve the overall quality of students}

Action-oriented teaching methods are integrated. Project tasks are accomplished through small groups and one task is divided and assigned to multiple students. Each student is able to learn by himself and enhance his ability to acquire knowledge when he is solely responsible for one task. At the same time, the project is completed by the students, which requires the students to constantly communicate with the team members in the learning process, cooperate with each other and learn from each other so as to improve students 'coordination ability and make students' knowledge system more comprehensive.

\section{Conducive to the construction of online courses}

On the basis of action-oriented teaching the online course of "financial statements analysis" can promote the interaction between teachers and students. Under the network environment, teachers and students can participate in discussions about some teaching contents during or after class, and teachers can also guide students in real time. Teachers in the teaching process have become the leader of learning, and the role of teachers through cases, tasks project guidance is fully utilized in online courses. In addition, online teaching resources are abundant so that students can get the information they needed in real-time and be personalized through Internet.

The construction of online courses is conducive to teaching effectiveness. Teachers design teaching unit tasks, projects and test questions evaluation indicators in the online course platform, students can evaluate every part of their learning and discover problems in time according to their own progress of learning. By summarizing each student's evaluation, the teacher can discover the problems timely during the process of their teaching. The evaluation of teachers and students and the online and offline interaction can promote the improvement of teaching effectiveness.

\section{CONCLUSION}

As declared in the first sentence of the Bologna Declaration, science and technology and education have no boundaries.[6] The German action-oriented teaching philosophy, based on practicality, emphasizing the cultivation of skills and practical abilities, aims to foster students' ability of employment, adaptation, competition and development in the future and develop their abilities to find, analyze, solve and summarize problems in the "Financial Statement Analysis" course and their operation, application capabilities, as well as a series of key capabilities such as independence, cooperation, communication, self-learning, etc..

\section{REFERENCES}

[1] Daihaishan, Chen Huifang. Action-oriented teaching in the practice of international trade practice research, shopping malls modernization, 2010 (5).

[2] Miao Yanfang. Action-oriented teaching model in the tax practice courses in enterprise applications, science and technology economic markets, 2016 (6).

[3] Zhao Rong, Yang Lei. "Practice of taxpayers" course-oriented teaching practice, Guangzhou City College, 2010 (03).

[4] Yi Kaigang, Li Feiqin, Peng Yan. Application-oriented classroom teaching model of practical teaching reform, Journal of Ningbo University, 2016 (3).

[5] Jiao Caili. The implementation principle of action-oriented teaching mode and teaching organization process, education and teaching research, 2015 (6).

[6] Lanxue Xia action oriented teaching reviews at home and abroad, human resources development, 2015 (5). 